\title{
Photovoltaic Technology Incubator Awards
}

\section{About the awards}

The photovoltaic (PV) technology incubator solicitation plays an integral role in President Bush's Solar America Initiative by enabling U.S. small businesses to accelerate prototype and precommercial PV technologies to pilot- and full-scale production. The selections include 10 projects that could receive up to $\$ 27$ million of DOE funding over the next 18 months subject to appropriations from Congress. Award recipients will contribute a minimum of $20 \%$ of funding for a total value of up to $\$ 71$ million.

\section{Why were these projects selected?}

This solicitation is structured to allow innovative approaches towards increasing the production of promising PV technologies. The selected companies have demonstrated a proof-of-concept PV device and proposed a clear path to ramping up production to 3 megawatts/yr or greater by 2010. In addition to higher production capacity, the projects will focus on device performance and reliability that directly translate into lower energy costs. This emphasis on market-focused product development will yield market-ready technology for residential and commercial markets as well as utility-scale power generation.

\section{About the technology development strategy}

The selected projects under this solicitation focus on technology improvement of PV modules, which include the use of diverse materials and innovative product designs. Successful projects will be positioned to apply for a second phase of the larger, industry-led technology development solicitation focusing on PV system cost reductions for market competitiveness by 2015 .

\section{How will these projects be funded?}

The funding structure for this solicitation is intended to be flexible and cyclical. The performance period of each project is 18 months with the possibility of project termination after a DOE stage gate review at month nine. The projects have been structured so that companies can receive their funding from DOE only upon successful delivery of pre-specified samples of new hardware. This approach will allow early-stage companies to focus on demonstration of technology, while assuring that taxpayers get the best value for their investment in these projects.

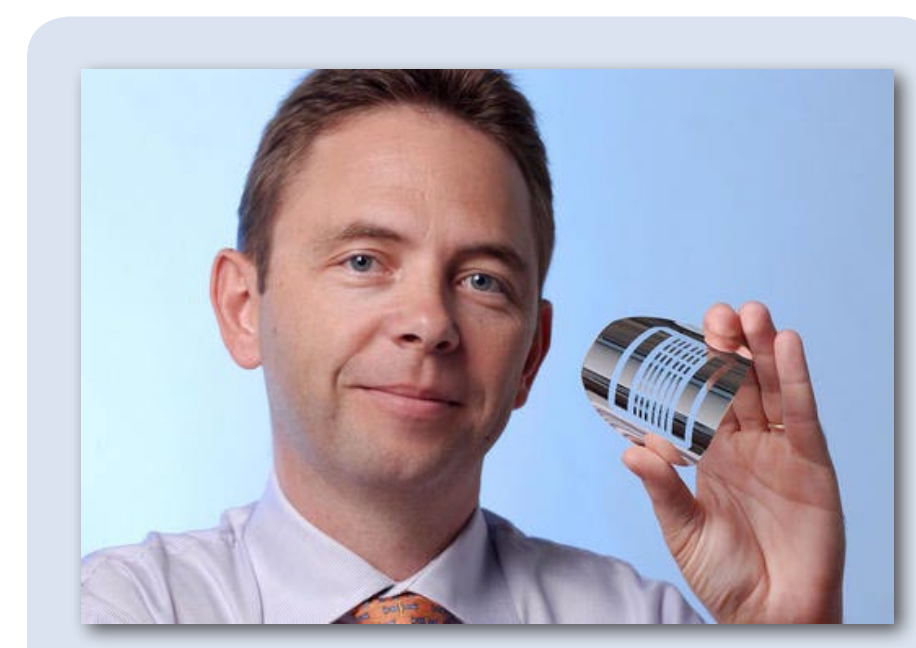

Professor Bernard Kippelen holding an electronic circuit fabricated on a flexible plastic substrate. The solar cells he is developing can be integrated with such organic electronic devices. Photo credit: Cappello, Nicole - Georgia Tech

To facilitate rapid cycles of innovation in the domestic PV sector, DOE will provide opportunities for new companies to enter this program every nine months, subject to Congressional appropriation.

\section{Initial PV Technology Incubator Awardees}

$\begin{array}{ll}\text { AVA Solar-Fort Collins, CO } & \text { MicroLink Devices-Niles, IL } \\ \begin{array}{l}\text { Blue Square Energy- } \\ \text { North East, MD }\end{array} & \text { Plextronics-Pittsburgh, PA } \\ \text { CaliSolar- } & \text { PrimeStar Solar-Golden, CO } \\ \text { Menlo Park, CA } & \text { Solaria-Fremont, CA } \\ \text { EnFocus Engineering- } & \text { SolFocus-Palo Alto, CA } \\ \text { Sunnyvale, CA } & \text { SoloPower-Milpitas, CA }\end{array}$




\section{SAI Across America}

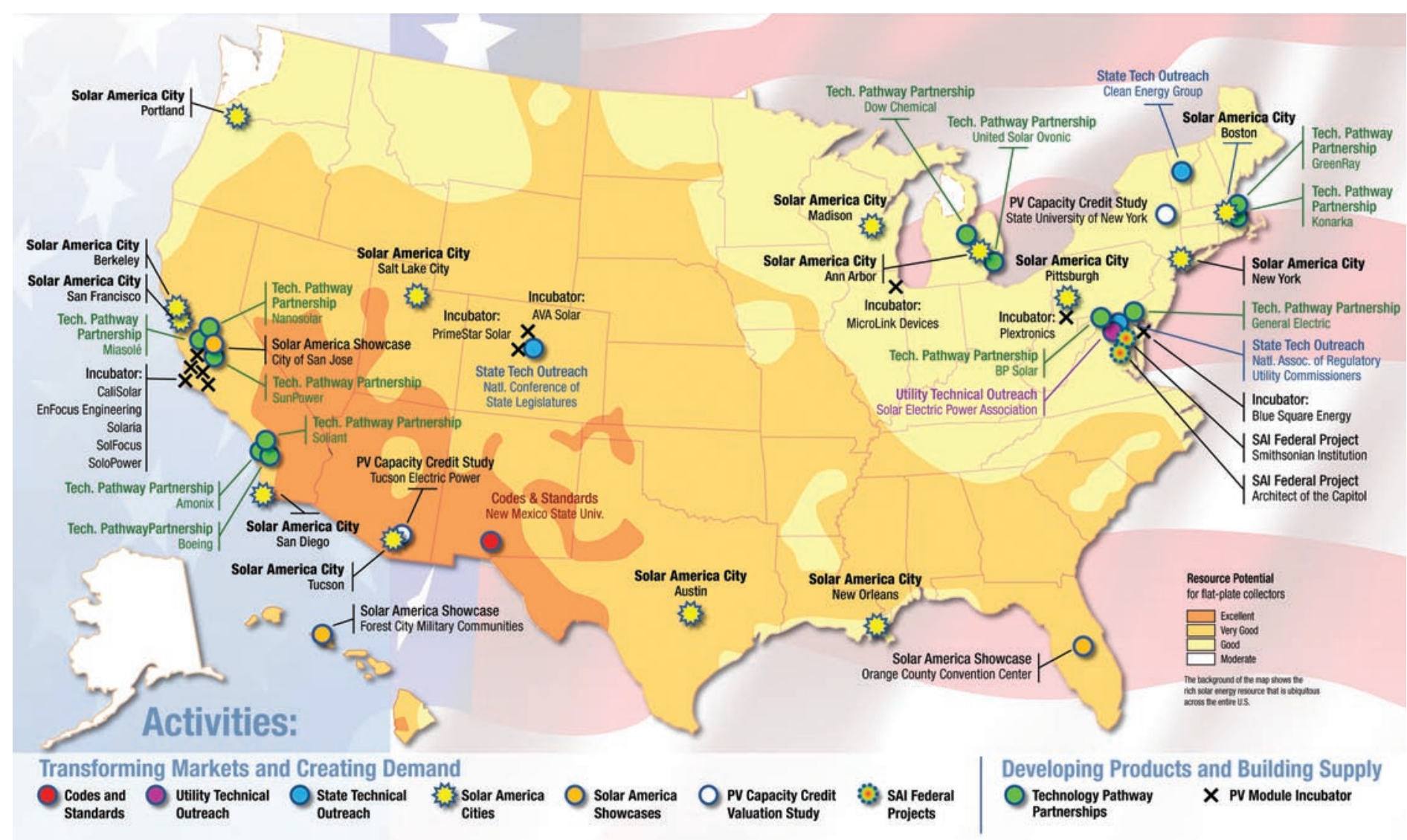

\section{Resources}

\section{About the Solar America Initiative}

President Bush launched the Solar America Initiative in 2006 with the goal of achieving cost-competitiveness for solar technologies across all market sectors by 2015. DOE is working to accomplish this goal through public-private partnerships with industry, universities, its national laboratories, state municipalities, and/or non-governmental organizations.
Office of Energy Efficiency and Renewable Energy: www.eere.energy.gov/

Solar America Initiative: www.eere.energy.gov/solar/solar_america

EERE Solar Program: www.eere.energy.gov/solar/photovoltaics.html

Database of State \& Local Incentives for Renewable Energy: www.DSIREUSA.org

Solar America Tour: www.eere.energy.gov/solar/solar_america

EERE State Activities \& Partnerships: www.eere.energy.gov/states

NREL Solar Energy Basics: www.nrel.gov/learning/re_solar.html

American Solar Energy Society (ASES): www.ases.org

Interstate Renewable Energy Council (IREC): www.irecusa.org/

U.S. Green Building Council (USGBC): www.usgbc.org

\section{Sponsored by the}

U.S. Department of Energy, Office of Energy Efficiency and Renewable Energy

For more information contact:

EERE Information Center

1-877-EERE-INF (1-877-337-3463)

www.eere.energy.gov

Prepared by the

National Renewable Energy Laboratory (NREL)

NREL is a U.S. Department of Energy National Laboratory

Operated by Midwest Research Institute $\bullet$ Battelle

\section{DOE/G0-102007-2445 • June 2007}

A Strong Energy Portfolio for a Strong America. Energy efficiency and clean, renewable energy will mean a stronger economy, a cleaner environment, and greater energy independence for America. Working with a wide array of state, community, industry, and university partners, the U.S. Department of Energy's Office of Energy Efficiency and Renewable Energy invests in a diverse portfolio of energy technologies.

Printed with a renewable-source ink on paper containing at least 50\% wastepaper, including $10 \%$ postconsumer waste. 